\title{
The Phenomenological Study of Fanaticism of Football PSS Sleman Supporters
}

\author{
Ricki Agusman \\ Master Program in Sport Sciences \\ Yogyakarta State University \\ Yogyakarta, Indonesia \\ ricki.agusman69@gmail.com
}

\author{
Caly Setiawan \\ Faculty of Sport Sciences \\ Universitas Negeri Yogyakarta \\ Yogyakarta, Indonesia \\ csetiawan@uny.ac.id
}

\begin{abstract}
- the aim of this study was to find out the factors of fanaticism, the extent to which fanaticism of BCS (Brigata Curva Sud) supporters of PSS Sleman's football club is supported and the steps needed to keep that fanaticism positive. This research made use of phenomenology study which is the description of the general meaning of some individuals to their various life experiences related to the concept or phenomenon. The main purpose of phenomenology is to bring about the reduction of an individual or group experience to a phenomenon in order to describe its universal essence. This research is a qualitative descriptive research. Data collection techniques were observation, interview and documentation. Data analysis techniques used include data reduction, data presentation and drawing of conclusions and verification. The results showed that most of the BCS (Brigata Curva Sud) supporters of soccer club PSS Sleman were young people; their fanaticism behaviors came as result of their behavioral exchange to gain existence, reputation, dominance; to show their impression of masculinity as reward, and the actual inner satisfaction they achieve in defending soccer club PSS Sleman to the level that they engage in violence and anarchy. The behavioral factors of fanaticism that maintain conflicts include maintenance of self-esteem, indoctrination in regeneration, mass media, social networking, provocative yells, and provocative symbol attributes with spiral conflict techniques that results in the attack of supporters of other clubs if there is any dispute. The conclusion of this research was that fanaticism is a manifestation of the totality of an individual to the club being supported by either positive or negative looking. The occurrence of violence can be as a result of many factors like historical factor, fanaticism factor, regional rivality factor, revenge factor, referee decision and factor of facilities or stadiums that are not adequate. There is categorization of factors that brings about violence of supporters into positive flow. This category makes use of empirical scientific methods in the confirmation of facts in the field as it relates to crime occurrence. Other classification include environmental theories in which crime is caused by the circumstances in the surrounding or the environment that turns people to evil ways as a result of the people or conditions they imitate.
\end{abstract}

Keywords—phenomenology, fanaticism, supporter

\section{INTRODUCTION}

Bad stigma attached to BCS PSS Sleman supporters cannot be separated from the role the media is playing at exposing interesting facts and possessing high news value. In a way that tends to be dramatic, the mass media have always preferred to present frays between supporters in their major headlines. The information gotten is no longer unstructured reality but rather a structured or organized reality which means that the picture is now being presented in its truest form.
There is possibility of an increased militancy by special support group of BCS in their usual negative ways. Supporters do not want to give up the ferocious predicate that has been given by the media. On the other hand, the opposing group will always enforce full alert status when faced with other groups that are considered rivals, on some occasions, the rivalry results in different challenges and interceptions on the streets (Nugroho Rizal S, 2013: 51).

Most times supporters forget the fact that the creation of football was majorly for the purpose of strengthening the relationship between the two camps that compete. In fact, the presence of this supporters in the stadium is not only to support, but also to "prey" on the people considered to be the opponent. They fight for the existence of their group and their own self-esteem. But this is football where there is new thing to be shown at every age. Moreover, fans present a million phenomena that will to show the eyes for anyone who watches it.

\section{Fanatic Supporters}

Fanaticism is a term that is used in referring to a belief or view of something in a positive or negative way with no theoretical backdrop or a foothold of reality but which is professed profoundly in such a way that it is difficult to straighten or change. Fanaticism can be said to be a sense of blind love to something a person likes, antipathy to the unfavorable and the embodiment of narrow selfishness.

While fanaticism itself is a philosophy or a logical consequence of social science or heterogeneity of the world, it is a form of solidarity among people that agree on a particular thing. Individuals who experience blind fanatics idolize or believe something to be the most correct and such thing is always good from their perspective. Fanaticism is the belief or paradigm about something the can be either positive or negative which is not based on any existing theory or reality and is believed in depth to the extent that it is difficult to straighten or change.

Emotion have long been considered antecedents of, critical to, and primary outcomes of consumption experiences $[5,6]$. Such emotions may be especially poignant in intercollegiate rivalries where a long history of bitterly fought competitions has to do with several generations of love or hate relationships. Along these lines, previous research works on sports marketing have placed focus on emotional involvement and attachment as drivers of sport consumption, and the 
measurement of attachment was done with items indicative of loyalty and fanaticism $[4,11,15]$.

Despite the fact that it shows some deep insight, this perspective apparently masks or ignores the underlying approach/avoidance behaviors associated with basic emotions [3]. As a result, this view largely discounts how particular emotional dimensions (e.g., arousal) influence sport consumption.

The emotions experienced are important to the understanding of consumer behavior in various situations, sports contexts inclusive [10], Raynaud \& Bolos, 2008). For example, fans that are highly identified with a team experience more positive emotions after their team win than lose, which may ultimately lead to team allegiance [2]. In other contexts like gift giving and receipt, donors and recipients report a wide range of positive and negative emotions before, during, and after the act $[13,14]$. In retail shopping contexts, there is possible monitoring of feelings as approach/avoidance indicators by consumers $[8,9]$ and individual differences in the regulation of emotions (action- (resulting from a circumstance) versus state- (a persistent feeling) oriented individuals) provide for immense different shopping behaviors which include varying reactions to environmental stimuli [1]. Emotions are also very important in the post-consumption evaluations of goods and services.

Solidarity is the unity that arises from the importance of the same feeling. The word originated from solid which means intact, unanimous, not split. Solidarity has a positive meaning because wholeness is used for things that are useful/constructive. There are is a great difference between solidarity and fanaticism. In fanaticism, the feeling of oneness that is seen is applied in bad/destructive things while solidary is a relationship that exists among individuals or groups as a result of moral feelings and beliefs they share with are further strengthened by the emotional experiences they have shared. This bond is found to be more fundamental than a contractual relationship made with rational approval.

Additionally, emotional bonding can be experienced between two individuals as well as between an individual with a group or organization. In groups, there are different circumstances between members that can result in a group becoming more solid or less solid. This is dependent on group cohesion, where the members love each other. The group begins with a sense of attraction among members, it can be concluded that there can be increment in the cohesiveness of the group as result of similarity, attitudes, values, personal traits, and demographic traits. If the requirements for entry into a group are more difficult then the levels of cohesiveness within the group are also higher.

The use of the theory of solidarity by researchers is founded on its suitability for the group of BCS (Brigata Curva Sud) supporters. An example of solidarity can also be discovered in the BCS group (Brigata Curva Sud) where there are similarities in their emotional attachments to support the Sleman PSS team. They are not bound or forced by anything. The love of the big name of PSS Sleman's team creates a connection between an individual and another individual. The relationship that exists between these individuals is the foundation of the Solidarity group of BCS supporters (Brigata Curva Sud).
This form of group solidarity is more visible when watching and supporting the PSS Sleman team starting from when then compactly enter the stadium in an orderly and regular manner until they render the sologan "No Ticket, No Game" which means that tickets should be bought in order to watch the matches. The members of the BCS are obliged to use the shoes, prepare to make koreo from long before the game and compactly showcase the kretative attractions of the koreo when watching PSS Sleman.

\section{RESEARCH METHODS}

This research made use of qualitative research methods to have the descriptive data of fanatic soccer supporters of BCS (Brigata Curva Sud). The research gathered descriptive data from the oral words of informants and observed behaviors. This study aimed to explore different sources of data that can be used to explain, describe, investigate and comprehend the forms of fanaticism that exists in the supporter group BCS (Brigata Curva Sud) supporting PSS Sleman and also to understand the factors that influenced their fanaticism behavior.

a. Primary data: This was gotten from interviews with informants as well as direct observations of the subject of the research.

\section{1) Research Subject}

Subjects in this study were about eight thousand members of the supporter group BCS (Brigata Curva Sud). This figure is an estimate of the central board of BCS due to the absence of clear data recapitulation related to the number of BCS members.

\section{2) Informants}

The informants in this study were general chairpersons or representatives who are both representatives and active members of BCS - both registered and non-registered. Supporting data was gotten from the surrounding community who becomes out-group BCS. The people who were members of the supporting informants were chosen to be two and are ordinary people close to the MIS (Maguwoharjo International Stadium) which is the stadium where BCS supports and others that are not officially incorporated in the BCS membership (Brigata Curva Sud) support the team when they compete.

\section{b. Secondary Data}

Secondary Data is additional data gathered to complete the primary data. In this study, the secondary data used include literature books, research documents such as photographs, archives, the Internet, literature related to supporters, research documents such as BCS photographs when they are supporting PSS Sleman, BCS governance archive and other works that are related to research on fanaticism of supporter group BCS (Brigata Curva Sud).

The data analysis technique that was used in this research include data collection, data reduction, data presentation, and conclusion which is in conformity with Miles and Huberman [7].

\section{RESEARCH RESULT}

The results show that the BCS supporters of soccer club PSS Sleman are young people, that their fanaticism behaviors are as a result of behavioral exchange to gain existence, 
reputation, dominance, the impression of masculinity as reward, and the actual inner satisfaction they derive by defending their soccer club PSS Sleman to the level of violence and anarchy. Fanatism's behavioral factors that maintain conflicts have been discovered to include maintenance of selfesteem, indoctrination in regeneration, mass media, social networking, provocative yells, and provocative symbol attributes with spiral conflict techniques that results in the attack of supporters of other clubs if there is any dispute.

\section{CONCLUSIONS}

The conclusion of this research was that fanaticism is a manifestation of the totality of an individual to the club being supported by either positive or negative looking. The occurrence of violence can be as a result of many factors like historical factor, fanaticism factor, regional rivality factor, revenge factor, referee decision and factor of facilities or stadiums that are not adequate. There is categorization of factors that brings about violence of supporters into positive flow. This category makes use of empirical scientific methods in the confirmation of facts in the field as it relates to crime occurrence. Other classification include environmental theories in which crime is caused by the circumstances in the surrounding or the environment that turns people to evil ways as a result of the people or conditions they imitate.

\section{REFERENCE}

[1] B. Babin, \& W. R. Darden, "Consumer self-regulation in a retail environment, ” Journal of Retailing, 1995, 71, 47-70.

[2] A. Bizman, \& Y. Yinon, Engaging in distancing tactics among sports fans: Effects on self-esteem and emotional responses. The Journal of Social Psychology, 2002, 142, 381-392.

[3] J. Elster, Emotions and economic theory. Journal of Economic Literature, 36, 1998, 47-74.

[4] G-Y. Koo, \& R. Hardin, Difference in interrelationship between spectator's motives and behavioral intentions based on emotional attachment. Sport Marketing Quarterly, 2008, 17, 30-43.

[5] G. F. Loewenstein, E.U. Weber, C. K. Hsee,., \& N. Welch, Risk as feelings. Psychological Bulletin, 127, 267-286. 2001.

[6] D. J. MacInnis, \& G. E. de Mello, The concept of hope and its relevance to product evaluation and choice. Journal of Marketing, 2005, 69, 114.

[7] B. M. Miles, dan M. Huberman. Analisis Data Kualitatif Buku Sumber Tentang Metode-metode Baru. Jakarta: UIP. 1992.

[8] M. T. Pham, The logic of feeling. Journal of Consumer Psychology, 14, 360-369. 2004.

[9] M. T. Pham, J. B. Cohen, J. W. Pracejus, \& G. D. Hughes, "Affect monitoring and the primacy of feelings in judgment," The Journal of Consumer Research, 2001, 28, 167-188.

[10] H. Preuss, The conceptualization and measurement of mega sport event legacies. Journal of Sport \& Tourism, 2007. 12, 207-227.

[11] M. J. Robinson, G. T. Trail, \& H. Kwon, Motives and points of attachment of professional golf spectators. Sport Management Review, 7, 167-192. 2004.

[12] J. A. Russell, \& A. Mehrabian, Evidence for a three-factor theory of emotions. Journal of Research in Personality, 11, 273-294. 1977.

[13] J. A. Ruth, "It's the feeling that counts: Toward an understanding of emotion and its influence on the gift exchange process, " In C. Otnes \& R. Beltramini (Eds.), Gift-giving: An interdisciplinary anthology (pp. 195-214). Bowling Green, OH: Bowling Green University Press. 1996.

[14] J. A. Ruth, C. C. Otnes, \& F. F. Brunel, Gift receipt and the reformulation of interpersonal relationships. The Journal of Consumer Research, 25, 385-404. 1999.

[15] G. T. Trail, M.J., Robinson, R. J., Dick, \& A. J. Gillentine, (2003). Motives and points of attachment: Fans vs. spectators in intercollegiate athletics. Sport Marketing Quarterly, 12, 217-227. 